\title{
Hatchel Site and Paul Mitchell Cemetery
}

\section{A. T. Jackson \\ Unknown}

Follow this and additional works at: https://scholarworks.sfasu.edu/ita

Part of the American Material Culture Commons, Archaeological Anthropology Commons, Environmental Studies Commons, Other American Studies Commons, Other Arts and Humanities Commons, Other History of Art, Architecture, and Archaeology Commons, and the United States History Commons

Tell us how this article helped you.

This Article is brought to you for free and open access by the Center for Regional Heritage Research at SFA ScholarWorks. It has been accepted for inclusion in Index of Texas Archaeology: Open Access Gray Literature from the Lone Star State by an authorized editor of SFA ScholarWorks. For more information, please contact cdsscholarworks@sfasu.edu. 


\section{Hatchel Site and Paul Mitchell Cemetery \\ Creative Commons License \\ (c) $($ ) $(9)$}

This work is licensed under a Creative Commons Attribution-NonCommercial 4.0 International License 


\title{
Hatchel Site and Paul Mitchell Cemetery ${ }^{1}$
}

\author{
A. T. Jackson
}

\section{HATCHEL SITE}

A WPA-University of Texas archaeological unit excavated in the vicinity of Texarkana from November 1, 1938, to August 25, 1939, on the A. J. Hatchel place [41BW3], Bowie County. During that time a large earthen mound and adjacent cemeteries were excavated under the direction of William C. Beatty, Jr.

The mound, 190 x 145 x 30 feet, was located on what seemed to be an old channel of Red River about a mile from the present stream. The site was part of an extensive village, perhaps related to other mound and village groups within a radius of three miles. The entire area, which contains nine or more mounds, shows evidence of long-continued occupation by fairly large numbers. The Hatchel mound had long served as a place of refuge for livestock in periods of overflow.

On top of the mound grew a large burr oak tree which had rings indicating an age of 170 years. There was no evidence of European contact.

The mound was not a burial structure, but a truncated pyramid of the house-mound type. Only four burials were found in the entire mound. Three of these were infants and one was an intrusive adult burial.

Eight floors were found in the upper 13 feet of the mound. The presence of so many floors in a small vertical area suggests that after each period of occupation, and possible burning of the house, more soil was added and another floor prepared for building purposes. Beneath the eighth floor was a primary mound of smaller proportions, at each end of which had been fills to enlarge for the next floor. The primary mound seemed to have a ramp, or slanting approach, at the south center.

The lower part of the mound consisted of two different structural stages. Most of the lower levels were almost sterile as compared with the evidences of material culture found on the upper floors. The original mound was erected on a portion of the large, comparatively level village site, and not on a natural elevation.

Each floor contained from one to three house sites, outlined by post molds. Of twenty houses, fifteen were roughly circular in shape. They ranged in size from 10 to 49 feet, with an average diameter of about thirty feet. A number of houses had protruding entranceways three to four feet wide and about five feet long, as indicated by post molds. Of fourteen definite entranceways, $57 \%$ were to the southeast, $22 \%$ to the south, $14 \%$ to the east, and $7 \%$ to the northwest. Wattle, apparently from burned clay roofs, was present in four of the houses. There was no evidence of a large central supporting post in any house.

Seven houses contained fire pits, while three others had deposits of ashes without definite pits. Most of the fire pits were near the centers of the houses. Eight houses had storage pits, some with two or three such pits containing rubbish. 
The topmost floor contained a house at the east and west ends, a large storage pit in the northwest corner. Between the two houses was a "compound-like" area that may have contained drying racks or lean-to shelters, as indicated by post molds.

On the sixth floor from the top was a central house with an almost perfect entranceway to the south. It consisted of seventeen well aligned holes, some of which contained the remains of cedar posts.

At the west end of, and beneath, the mound on the old village level was a large circular house site, divided by a partition into two "rooms."

Aside from the grave goods, consisting mostly of pottery vessels and many scattered potsherds, the material culture was scantily represented in the mound. The projectile points, mostly small, were of the stemmed and unstemmed varieties; the former had expanded and contracted stems, the latter had straight and concave bases. A cache of sixteen small triangular points lay in a heap.

Many fragmentary pipes were found, as well as an occasional broken vessel. Two unusually large polished stone celts were on the floor very near each other. Among the ornaments were bear-tooth pendants and a turquoise bead.

In addition to the seemingly significant practice of burying infants in the mound, other facts suggest that this large mound may have been the abode of important individuals and their families. There also remains the possibility of the mound having been the location of a "town house" or so-called temple.

As indicated by Beatty, the mound suggests the division of its growth into five periods. The first represented the occupation of the original village that later was covered by the mound. This consisted of two additions, the lower of which may have been merely a clay base for the next higher addition. The third period, consisting of end additions to the mound and the erection of five additional floors, may be called the period of large occupational levels. The fourth is a period of smaller occupational levels, and includes the last three floors added to the mound. The final period, since abandonment by the Indians, shows the results of floods, erosion and heavy wind deposits.

A few hundred feet to the east of the large mound were exhumed sixteen burials with which were deposited sixteen crude pottery vessels and one clay pipe. The depth of the graves ranged from four to forty inches. There was no evidence of European contact, and the skeletal material was in a very poor state of preservation. These facts, coupled with the crudeness and scarcity of pottery, suggest that the burials may have been early prehistoric.

In a village site to the southeast of the mound three burials were found; and to the southwest of the mound were ten other burials. This made a total of twenty-nine graves adjacent to the mound, with only four in it. There probably are other burials in the nearby field, where no excavation was done due to farm operations.

Among the pottery fragments from the Hatchel site was one rim sherd different from all others. It has a flat rim with two incised lines in the lip of the rim. This is suggestive of a certain ware from Louisiana reported by J. A. Ford. ${ }^{2}$ 


\section{PAUL MITCHELL CEMETERY}

A burial site was discovered a number of years ago on the Paul Mitchell place [41BW4] on McKinney Bayou, one mile south of the Hatchel mound, Bowie County. Many skeletons are said to have been destroyed while building a levee at that place. Considerable digging subsequently was done by local amateurs. A WPAUniversity of Texas crew excavated the remainder of the cemetery from November 10, 1938 to January 10, 1939. A. M. Woolsey was in charge.

Fifty-seven burials were exhumed. They were in an extended position, and the majority were oriented with the head to the southeast. The graves were about $6 \times 3$ feet and had an average depth of 30 inches. Most of the skeletal material was in a good state of preservation.

There were more mortuary offerings in the graves, the pottery was of a better workmanship and more ornately decorated than at the nearby Hatchel cemetery. There was, however, no evidence of European contact. These facts indicate that the Mitchell burials are more recent than those at the Hatchel place, but that they are not historic.

In all of the burials at the Mitchell place many small pieces of charcoal were found in the grave fill. This probably resulted from the use of fire in the burial ceremonies.

In one grave was what appeared to be a food offering for the dead. One of the three pottery vessels, a small black jar, had inside — and outside near the mouth — the bones of a squirrel. The grave also contained a clay pipe, two bone needles, a polished stone celt, a flint scraper, and twelve small pieces of deer hoof.

Outstanding specimens recovered from this burial site included an earthenware pipe of the so-called T-shape, with a delicate bowl and a long stem that extended to the rear of the bowl; an ornately worked shell gorget; and five bone arrowpoints with definite stems.

\section{NOTES}

1. Reprinted from Texas Archaeological News No. 2 (December 1940), an Occasional Report issued by The Council of Texas Archaeologists.

2. Ford, J. A., Ceramic Decoration Sequence at an Old Indian Village Site Near Sicily Island, Louisiana, Anthropological Study No. 1, Louisiana Geological Survey, New Orleans, 1935, pp. 15, 25. 